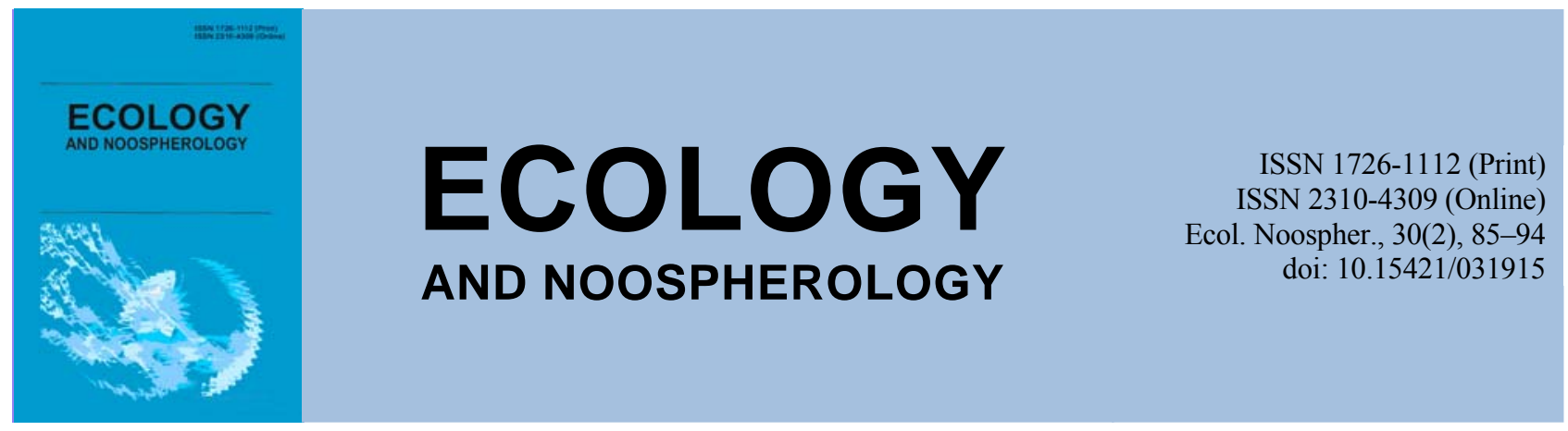

\title{
Influence of seasonal climatic factors on the dynamics of birds interactions with oaks consortia
}

\author{
O. L. Ponomarenko, M. V. Shulman
}

Oles Honchar Dnipro National University, Dnipro, Ukraine

Article info

Received 11.11.2019

Received in revised form

17.11.2019

Accepted 22.11.2019

Oles Honchar Dnipro

National University,

Gagarin Ave., 72, Dnipro,

49010, Ukraine.

Tel.: +38-066-439-05-72

E-mail: aponomar@ua.fm
Ponomarenko, O. L., Shulman, M. V. (2019). Influence of seasonal climatic factors on the dynamics of birds interactions with oaks consortia. Ecology and Noospherology, 30(2), 85-94. doi:10.15421/031915

The article is devoted to the bird communities in individual oak consortia (Quercus robur L.) of the linden-ash oak forests. This work material was collected during different seasons of the 20042010 years in a linden-ash oak grove on the test plot No. 209 of the ecological profile of the NSC «Bel'gard Prisamar'e International Biospheric stationary», Novomoskovsk district, Dnepropetrovsk region. The individual consortia of 281 examples of three age conditions oak trees (virgins - virg, young generative $-\mathrm{gl}$, mature and old generative individuals $-\mathrm{g} 2-\mathrm{g} 3$ ) has been investigated. The daily time budget decreases by $2-2,5$ times in autumn for all oak ages that have been studied. But the number of consort birds is reduced by 2 times only for virgin and old generative oaks. The young generative oak is attractive enough for birds in autumn. The ratio of the trophic and topical share interactions for all trees ages does not change significantly in autumn. Birds don't interact with the virgin oak in winter practically. This age oak can't propose enough food or places for birds' protection from predators. Oaks in age g1-g3, on the contrary, are in demand by the birds. There 7 birds species on g1 oaks and 13 species on g2-g3 oaks were recorded in winter. The birds' daily time buds for the one oak example are low in winter, and by the 90 times reduce compared with the summer. The bird time budget basis in winter are the trophic interactions. The birds' activity on oak sharply increases in spring and exceeds 1,5-2 times the summer parameters on virgin and mature generative oak (g2g3). Birds on oak spend most of their time on topical interactions during this season because of the oak important role in the birds reproduction. On the other hand, the young generative oak (g1) is not in demand by the birds in spring because of insufficient crown density and the oaks of this age location at the edge. The number of bird species on oak in spring is less than in summer due to the late onset of leaf blooming on the oak. A significant part of the birds' activity in the spring moves to the lower tier of the forest because of the earlier vegetation beginning. As a result of the research, it was revealed that the consorting groups of common oak throughout the year retain the main features of their organization. The virgin oak is characterized by a stochastic nature of the birds interaction with the consortium core and almost hasn't obligate consort birds. Young generative oak is actively forming a trophic relations system with consorts due to intensive linear growth. At this age, first of all, general indicators are formed - time and mass budgets. The consortium of mature and old generative oak has a significantly larger number of bird species consorts and their interactions diversity with the tree. This can help to increase the stability of consorting groups. In most cases in the oak consortium the trophic component of the consortium form earlier then the topical. The specific location of the virgin and young generative oak at the lit positions in the lime-ash oak forests influences the oak consortia formation in a considerable scale. The number of types of interactions between the consort and the autotroph is the most effective indicator, which shows a high level of the consortium development. The stability of consortial relations between birds and English oak grows throughout the year from virgin oak to mature and old generative. The virgin oak unstable consorting groups have fluctuations of the species number during the year up to $100 \%$ (the number of consort species in summer was chosen as the initial value). The consortia species composition fluctuations reach $81,82 \%$ for young generative oak, and 59,26 \% - for mature and old generative oak. The mature and old generative oak consortia attract seasonal bird species that replace each other throughout the year more actively. This ensures the stability of year-round control of phytophage populations.

Keywords: birds; oak; consortia; consortia interactions; dynamics during the year 


\title{
Вплив сезонних кліматичних факторів на динаміку консортивних зв'язків птахів з дубом звичайним
}

\author{
О. Л. Пономаренко, М. В. Шульман
}

Дніпровський національний університет імені Олеся Гончара, Дніпро, Украӥна

Стаття присвячена угрупованням птахів в індивідуальних консорціях такого едифікатора липово-ясеневих дібров, як дуб звичайний (Quercus robur L.). Матеріал даної роботи збирався у різні пори року 2004-2010 рр. у липово-ясеневій діброві із зірочником на пробній площі № 209 екологічного профілю ННЦ «Присамарський міжнародний біосферний стаціонар ім. О. Л. Бельгарда», Новомосковський район, Дніпропетровська область. Дослідженням було піддано індивідуальні консорції 281 екземпляра дуба звичайного трьох вікових станів (віргінільні особини - virg, молоді генеративні - gl, зрілі та старі генеративні особини - g2-g3). В результаті досліджень було виявлено, що консортивні угруповання дуба звичайного протягом усього року зберігають основні риси своєї організації. Віргінільний дуб має стохастичний характер взаємодії птахів з ядром консорції, характеризується практично повною відсутністю облігатних консортів-птахів. Молодий генеративний дуб за рахунок інтенсивного лінійного росту активно формує систему трофічних зв'язків з консортами, перш за все створюючи загальні показники - бюджети часу та маси. Консорція зрілого та старого генеративного дуба значно розширює кількість видів птахів-консортів та урізноманітнює характер їхньої взаємодії. Це може сприяти підвищенню стабільності консортивних угруповань. У більшості випадків у консорціях дуба першою формується трофічна складова консорції, потім топічна. Значною мірою на функціонування консорцій дуба впливає специфічне розташування віргінільного та молодого генеративного дуба на освітлених позиціях у липово-ясеневих дібровах. Найбільш ефективним показником, який свідчить про високий рівень розвитку консорції, є кількість видів взаємодій між консортом та автотрофом. Стабільність консортивних зв'язків птахів з дубом звичайним протягом усього сезону зростає у напрямку від віргінільного дуба до зрілого та старого генеративного. Нестійкі консортивні угруповання віргінільного дуба мають коливання за кількістю видів протягом року до $100 \%$ (за вихідну величину обрано кількість видів улітку), угруповання молодого генеративного дуба - 81,82 \%, зрілого та старого генеративного дуба - 59,26 \%. Таким чином, протягом року консорції зрілого та старого генеративного дуба найбільш активно приваблюють сезонні види птахів, які взаємозамінюють один одного. Цим досягається цілорічна стабільність контролю за популяціями фітофагів.

Ключові слова: птахи; дуб звичайний; консорція; консортивні взаємодії; динаміка протягом року

\section{Вступ}

Консорції є функціональною одиницею біогеоценозу, що автоматично свідчить про необхідність їх дослідження. Загальні схеми консортивних зв'язків на рівні популяцій вже давно встановлені, але слід зауважити, що рівень дослідженості індивідуальних консорцій ще явно недостатній. 3 іншого боку, саме різноманіття індивідуальних консорцій $є$ тією основою, яка створює величезне різноманіття типів біогеоценозів. Актуальним питанням залишається і динаміка консортивних зв'язків, яка на рівні індивідуальних консорцій також залишається «білою плямою». Загалом наукові праці щодо участі птахів в системі консортивних зв'язків уже досить численні (Ponomarenko, 2005, 2006, 2007; Tryfanova et al., 2015; Yuzyk, Chaplygina, 2015; Chaplygina et al., 2016a, 2016b). 3 іншого боку, в цих наукових працях висвітлюються питання розвитку системи консортивних зв'язків птахів протягом онтогенезу ядра консорції, функціональний склад птахів-консортів, їх чисельність та просторовий розподіл, але питання міжсезонної динаміки консортивних зв'язків птахів в індивідуальних консорціях практично не розглядалися. Ця стаття присвячена аналізу динаміки участі птахів в індивідуальних консорціях дуба звичайного трьох вікових груп протягом року.

\section{Об’єкти та методи досліджень}

В основу методологічного підходу досліджень покладено вчення В. М. Сукачова (Sukachev, 1972) про біогеоценоз, типологію штучних i природних лісів степової зони О. Л. Бельгарда (Belgard, 1971), вчення В. І. Беклемішева (Beklemishev, 1951), Л. Г. Раменського (Ramenskiy, 1952), В. В. Мазинга (Mazing, 1966) про консорції.

Матеріал даної роботи збирався в різні пори року 2004-2010 pр. у липово-ясеневій діброві із зірочником (пробна площа № 209 екологічного профілю ННЦ «Присамарський міжнародний біосферний стаціонар ім. О. Л. Бельгарда»). Для дослідження консортивних зв'язків птахів за об'єкти було обрано індивідуальні консорції дуба звичайного (Quercus robur L.). Дослідженням було піддано індивідуальні консорції 281 екземпляра дуба звичайного трьох вікових станів (віргінільні особини - virg, молоді генеративні - gl, зрілі та старі генеративні особини - g2-g3). Віковий стан детермінантів консорції визначався за Смирновою із співавторами (Smirnova et al., 1976). Як основний методичний прийом для вивчення консортивних зв'язків птахів було використане хронометрування бюджету часу птахів (Dolnik, 1982) у модифікації, запропонованій О. Л. Пономаренко (Ponomarenko, 2005). Матеріал збирався по чотирьох сезонах: навесні, влітку, восени та взимку.

Дуб звичайний (Quercus robur) є домінантом серед порід липово-ясеневих дібров. Цей вид належить до щільнокронних порід (Belgard, 1971). Завдяки особливостям свого габітусу та онтогенезу дуб звичайний $є$ надзвичайно потужним середовищеутворювачем у дібровах. Він бере активну участь у формуванні верхнього ярусу природних лісових масивів, у тому числі i на площах біогеоценологічного профілю Присамарського біосферного стаціонару.

У липово-ясеневих дібровах дуб звичайний утворює відносно стиснуту, або шатрову (розкидисту) крону 3 середнім рівнем щільності облиствіння (Grigorenko, Lyindya, 1977). Пора цвітіння настає одночасно з розпусканням листя (Tkachenko, 1955), у кінці квітня - травні.

Дуб вирізняється повільним ростом у молодому віці, до 5-10 років (Tkachenko, 1955). У перший рік він виростає до висоти 20-30 см, далі кущиться і слабо піднімається в ріст (Tkachenko, 1955). Характерною рисою дуба є те, що він утворює досить значний самосів на досліджуваних площах, але пагони самосіву через 2-3 роки за браком світла гинуть. 3 початком нового циклу вегетації самосів випускає нові пагони зі сплячих бруньок (Tkachenko, 1955). Фактично молоде покоління цієї породи чекає поки завершать свій життєвий цикл та випадуть із деревостану екземпляри більш швидкоростучих та менш довговічних порід. Коли синильні екземпляри цих порід випадають, то у цей період молодий дуб активно користується світловим вікном, яке утворюється у деревостані (Tkachenko, 1955). 
Таким чином, відновлення популяції дуба звичайного у липово-ясеневих дібровах відбувається на освітлених позиціях, де є самосів, або жолуді переносяться тваринами. Це пояснює той факт, що основна кількість віргінільного та молодого генеративного дуба зустрічається на узліссях та освітлених «вікнах» самих липово-ясеневих дібров. Усі ці особливості розвитку даної породи впливають на формування іiі консортивних угруповань, у тому числі і на участь у них птахів.

На досліджуваних ділянках дуб звичайний переважно представлений паростевими генераціями віком 60-100 років (Grigorenko, Lyindya, 1977). Висота досліджуваних дубів коливалася в межах 22-25 м у зрілому та старому генеративному стані $(g 2-g 3), \quad 12-15$ м - у молодому генеративному стані $(g l)$ та 3,5-7 м - у віргінільному стані $(v)$. Розмах крони становив 12-20 м, 6-9 м та 2,5-5 м відповідно.

\section{Результати та їх обговорення}

Осінній період у функціонуванні консортивних угруповань птахів дуба звичайного характеризується досить значними змінами порівняно 3 літом. Це пояснюється декількома явищами у житті птахів. Головним $\epsilon$ процес розпаду гніздових угруповань, характерних для липово-ясеневих дібров. Це призводить, 3 одного боку, до зникнення групи літніх видів, з іншого до появи кочівних груп осідлих видів, які часто залишаються зимувати. Необхідно відзначити, що осінній період $\epsilon$ часом відгодовування сімейних груп птахів. Усе вищевказане призводить до збіднення видового складу птахів-консортів дуба, поступового формування зграй птахів з частково інтегрованою схемою трофічних зв'язків і вкрай нестабільним режимом взаємодії птахів-консортів 3 детермінантом консорції.

Консортивне угруповання птахів віргінільного дуба восени характеризується дуже бідним складом - 3 види (рис. 1, $A$ ). Загальний бюджет часу зменшується порівняно 3 літнім більш ніж у 2 рази (див. табл. 1). Трофічна складова даного виду консортивного угруповання птахів $\epsilon$ переважаючою.
Бюджет маси трофічних зв'язків птахів зменшився в 1,2 разу порівняно $з$ літнім (див. табл. 1). Таке співвідношення бюджету часу та маси птахів свідчить, що частота появи птахів на віргінільному дубі в осінній період мало змінилася, але птахи набагато менше часу проводять у взаємодії 3 детермінантом консорції. Це $\epsilon$ наслідком суттєвого зменшення чисельності птахів у липовоясеневих дібровах в осінній період. Трофічні зв'язки у консорції віргінільного дуба восени має тільки один вид синиця велика. Вона виявляє активність у другому та третьому концентрах. Цей вид є одним із небагатьох, які в даний сезон сімейними групами відгодовуються в деревостані липово-ясеневих дібров.

Топічна складова консорції віргінільного дуба вирізняється загальним низьким показником бюджету часу і має у своєму складі взаємодії трьох видів птахів. За цим показником вона поступається літньому варіанту у 2 рази (див. табл. 1). У складі топічних зв'язків птахів 3 дубом зафіксовано 3 ї різновиди. У цьому відношенні принципових відмінностей від літніх консорцій віргінільного дуба немає. Домінантом топічної складової $\epsilon$ сойка, субдомінантом - велика синиця. Особливу увагу необхідно звернути саме на сойку, оскільки іiі активна участь у цьому консортивному угрупованні пов'язана 3 появою іншого типу консортивних зв'язків - форичних. На освітлених позиціях у діброві та узліссях сойка часто влаштовує свої «комори» 3 досить великою кількістю жолудів дуба. Відповідно форична активність сойки у зонах розташування віргінільного дуба позитивно відбивається на його консорції.

Консортивне угруповання молодого генеративного дуба $\epsilon$ цікавим винятком із загальних тенденцій зміни функціональних взаємодій в осінній період. Одержані загальні показники $\epsilon$ найвищими серед консортивних угруповань птахів деревних порід в осінній період (див. табл. 1). Трофічна складова $\epsilon$ переважаючою - 74 \% від загального бюджету часу, топічна - відповідно $26 \%$. Бюджет маси трофічних зв'язків восени зменшується приблизно в 1,5 разу (див. табл. 1). У консортивне

Таблиця 1

Характеристика консортивних зв'язків птахів у консорціях дуба звичайного

\begin{tabular}{|c|c|c|c|c|}
\hline \multirow{2}{*}{ Сезон } & \multirow{2}{*}{ Параметри системи зв'язків } & \multicolumn{3}{|c|}{ Віковий стан } \\
\hline & & $v$ & gl & $g 2-g 3$ \\
\hline \multirow{5}{*}{ Літо } & Бюджет часу, сек. & $111,6 \pm 38,7$ & $1358,6 \pm 63,7$ & $1856,26 \pm 100,2$ \\
\hline & Бюджет маси, г & $37,44 \pm 2,3$ & $867,48 \pm 43,5$ & $321,53 \pm 23,52$ \\
\hline & Кількість видів консортів & 6 & 11 & 27 \\
\hline & Доля трофічних зв'язків, \% & 54,8 & 78,1 & 40,3 \\
\hline & Доля топічних зв'язків, \% & 45,2 & 21,9 & 59,7 \\
\hline \multirow{5}{*}{ Осінь } & Бюджет часу, сек. & $51,4+8,1$ & $724,85+42,2$ & $676,79+40,8$ \\
\hline & Бюджет маси, г & $29,6+5,6$ & $207,98+13,3$ & $256,20 \pm 12,81$ \\
\hline & Кількість видів консортів & 3 & 10 & 11 \\
\hline & Доля трофічних зв'язків, \% & 68,5 & 74,2 & 75,7 \\
\hline & Доля топічних зв'язків, \% & 31,5 & 25,8 & 24,3 \\
\hline \multirow{5}{*}{ Зима } & Бюджет часу, сек. & $12,1 \pm 3,2$ & $24,57 \pm 7,2$ & $20,64 \pm 4,48$ \\
\hline & Бюджет маси, г & 0 & $2,18 \pm 0,38$ & $3,39 \pm 2,18$ \\
\hline & Кількість видів консортів & 1 & $\overline{7}$ & 13 \\
\hline & Доля трофічних зв'язків, \% & 0 & 89,4 & 92,2 \\
\hline & Доля топічних зв'язків, \% & 100 & 10,6 & 17,8 \\
\hline \multirow{5}{*}{ Весна } & Бюджет часу, сек. & $218,75 \pm 11,45$ & $343,07 \pm 17,15$ & $2548,67 \pm 127,4$ \\
\hline & Бюджет маси, г & $30,8 \overline{7} \pm 5,7$ & $54,16 \pm 5,74$ & $292,14 \pm 14,62$ \\
\hline & Кількість видів консортів & 5 & $1 \overline{6}$ & $2 \overline{2}$ \\
\hline & Доля трофічних зв'язків, \% & 20,4 & 47,7 & 36,7 \\
\hline & Доля топічних зв'язків, \% & 79,6 & 52,3 & 63,3 \\
\hline
\end{tabular}

угруповання молодого генеративного дуба восени входить 10 видів птахів. Облігатними консортами $є$ велика синиця та вільшанка.
Трофічна складова цієї консорції досить багата на види усі 10 живляться в кроні дуба та на його стовбурі (рис. 1, Б1, Б2). Співвідношення навантаження на концентри за 


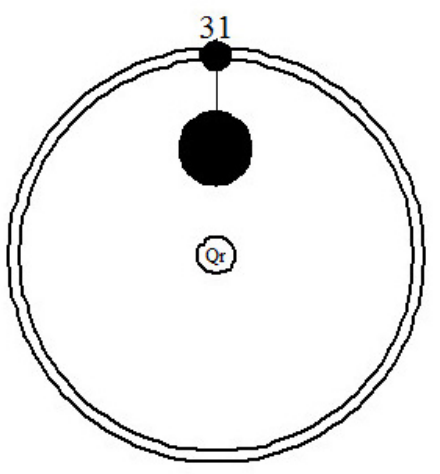

1

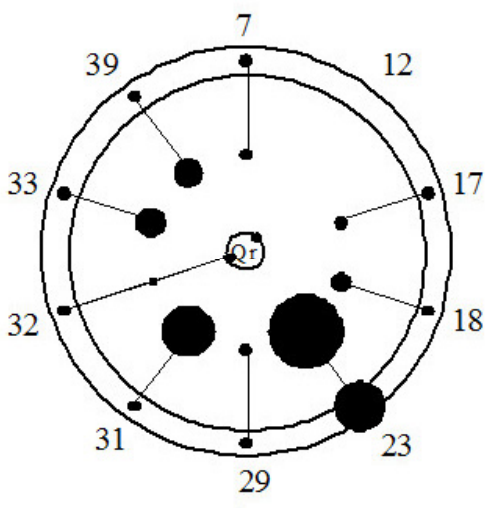

1

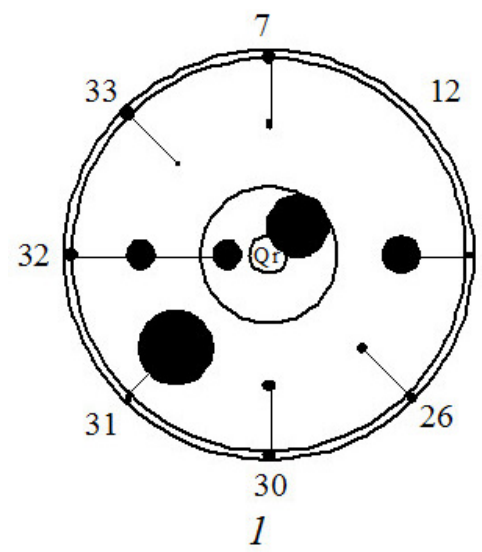

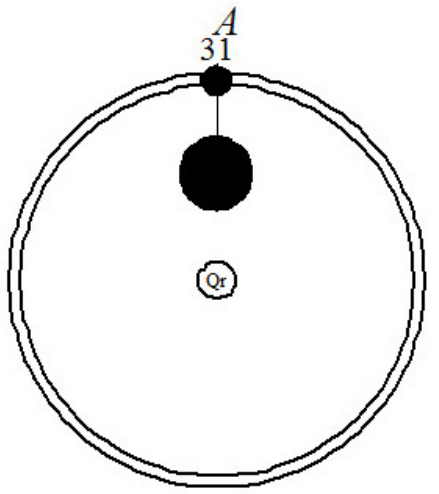

2

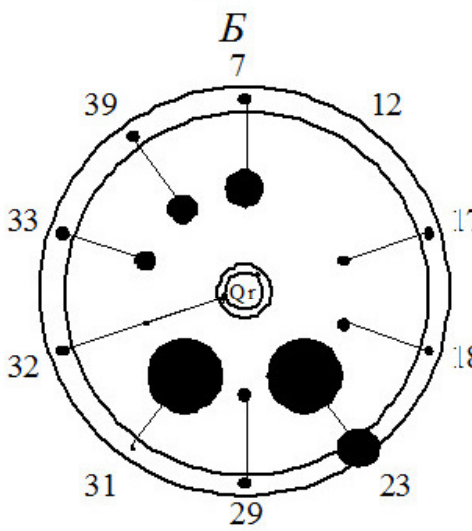

2

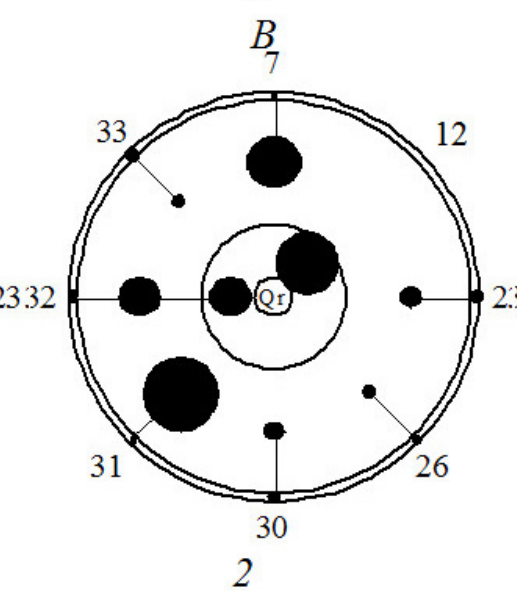

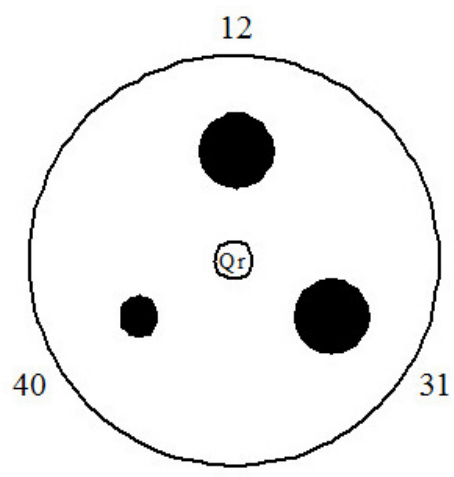

3

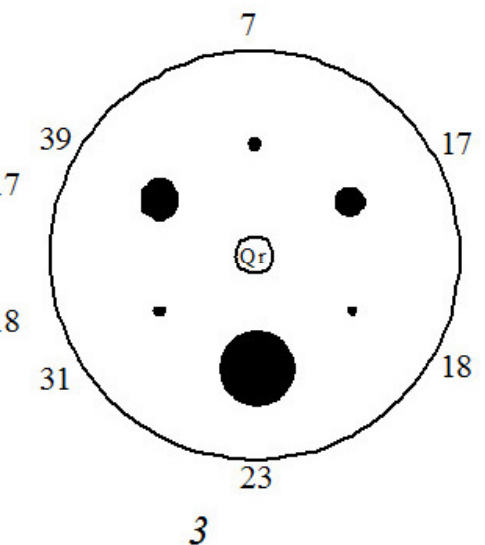

3

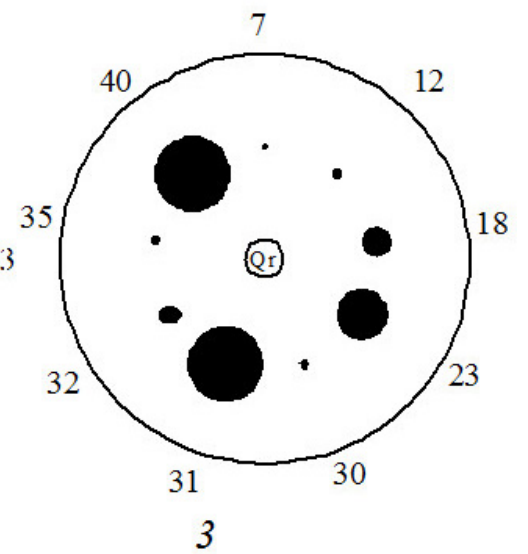

Рис. 1. Схеми консортивних зв’язків птахів з дубом звичайним за бюджетами часу та маси на один екземпляр автотрофа в осінній період:

А - віргінільним $-v$; Б - молодим генеративним $-g 1 ; \mathrm{B}-$ зрілим та старим генеративним $-g 2-g 3$;

1 - трофічних зв'язків за бюджетом часу; 2 - трофічних зв'язків за бюджетом маси; 3 - топічних зв'язків за бюджетом часу.

Номерами на схемах позначено консортивні зв'язки видів: 1 - Accipiter gentilis; 2 - Buteo buteo; 3 - Cuculus canorus;

4 - Strix aluco; 5 - Jynx torquilla; 6 - Picus canus; 7 - Dendrocopos major; 8 - Dendrocopos medius; 9 - Dendrocopos mino;

10 - Anthus trivialis; 11 - Oriolus oriolus; 12 - Garrulus glandarius; 13 - Corvus cornix; 14 - Bombycilla garrulus;

15 - Sylvia atricapilla; 16 - Sylvia curruca; 17 - Sylvia communis; 18 - Phylloscopus collybita; 19 - Phylloscopus sibilatrix;

20 - Muscicapa striata; 21 - Ficedula hypoleuca; 22 - Ficedula albicollis; 23 - Erithacus rubecula; 24 - Luscinia luscinia;

25 - Turdus merula; 26 - Turdus philomelos; 27 - Turdus viscivorus; 28 - Aegithalos caudatus; 29 - Parus caeruleus;

30 - Parus palustris; 31 - Parus major; 32 - Sitta europaea; 33 - Certhia familiaris; 34 - Passer montanus; 35 - Fringilla coelebs; 36 - Chloris chloris; 37 - Carduelis carduelis; 38 - Pyrrhula pyrrhula; 39 - Coccothraustes coccothraustes; 40 - Emberiza citrinella.

бюджетом часу таке: (перший - 0,79 \%, другий $-84,15 \%$, третій - 15,06 \%). Активна участь птахів у третьому концентрі пояснюється, за даними багатьох авторів (Apostolov, Bulakhov, Gubkin, 1968; Gubkin, 1979; Korolkova, 1963, Romaneev, 1973), зменшенням чисельності фітофагів восени і тому більшою частотою поїдання інших природних ентомофагів. Домінантом $\epsilon$ вільшанка, субдомінантами - велика синиця і за бюджетом маси - звичайний дятел. Дольова участь інших видів птахів коливається в межах 0,39-7,21 \% від бюджету часу трофічних зв'язків. Осінній період $є$ сезоном активності птахів у відношенні першого концентру. Одним 3 консортів молодого генеративного дуба $\epsilon$ сойка. За матеріалами польових спостережень сойка на молодих генеративних дубах збирала лише жолуді і не здобувала інших кормових об'єктів. Це явище $\epsilon$ класичним прикладом сполучення трофічних та форичних зв'язків. Мала дольова участь цього виду у загальному бюджеті 
часу свідчить про те, що дуб цієї вікової категорії не дуже привабливий для птахів-споживачів першого концентру. Крім сойки, активність у першому концентрі виявляє також повзик. На відміну від літнього типу живлення, восени цей вид досить активно споживає жолуді, роздовбуючи їх або ховаючи про запас на зиму. На відміну від сойки, він також виявив активність і в здобуванні комах. Живлення повзика жолудями, з нашої точки зору, не можна назвати сполученням трофічної та форичної активності, тому що, за даними спостережень, восени в липово-ясеневих дібровах повзик у $100 \%$ випадків ховав запаси жолудів у тріщинах кори та дуплах. Таким чином він вибирав їх 3 циклу відновлення популяції дуба. Крім того, рівень активності даного виду досить незначний і не може впливати докорінним чином на розповсюдження жолудів молодого генеративного дуба. Загалом високий рівень активності трофічних зв'язків птахів у консорції молодого генеративного дуба пояснюється його переважним розташуванням на освітлених позиціях на узліссі дібров. Значну частину консортивного навантаження складають мігруючі види (вільшанка, вівчарик-ковалик, сіра кропив'янка), які повільно переміщаються по узліссях, відгодовуючись для осіннього перельоту.

Топічна складова даного виду консорції (рис. 1, Б3) також відчуває на собі вплив мігруючих видів птахів. Восени топічні зв'язки 3 молодим генеративним дубом відмічено для 6 видів птахів. Незважаючи на досить незначний обсяг (див. табл. 1), вона має досить високий рівень різноманіття видів топічного зв'язку. Усього їх було зафіксовано 5 видів. Але, з іншого боку, усі п'ять виявив тільки один вид - вільшанка, яка є домінантом за обсягом топічних зв'язків. Інші види виявили від 1 до 3 видів зв'язку. Це свідчить про те, що саме мігруючі птахи $\epsilon$ активним компонентом у консорціях цієї вікової категорії дуба звичайного.

Осіннє консортивне угруповання зрілого та старого генеративного дуба $(g 2-g 3)$ за деякими показниками поступається молодому генеративному. Загальний показник бюджету часу менший у 1,07 разу (див. табл. 1). Основу його, як і у молодого генеративного, складають трофічні зв'язки $-512,38 \pm 25,6$ сек. ( $75 \%$ від загального бюджету часу). Бюджет маси більший, ніж у молодого генеративного дуба. За характером взаємодії 3 вищенаведеного виходить, що птахи частіше з'являються на старому дубі, але не затримуються надовго, перелітаючи на інші дерева. Це підтверджується також i середнім часом перебування на дереві кожного птаха, у молодого генеративного дуба - 53,12 сек., у зрілого та старого - 44,5 сек. За спостереженнями, в осінній період птахи живляться більш високими темпами, ніж улітку, тому збирають тільки найбільш доступний корм і надовго на одному дереві не затримуються. Топічна складова практично не поступається такій у молодого генеративного дуба (див. табл. 1). Загалом консортивні зв'язки із зрілим та старим генеративним дубом мають 11 видів птахів.

Трофічна схема зв'язків птахів з дубом $g 2-g 3$ (рис. 1, $B 1, B 2)$ дещо поступається такій у молодого генеративного дуба за кількістю видів - 7. Але принциповою відмінністю $\epsilon$ те, що основу іiї складають немігруючі види. Домінантом $\epsilon$ велика синиця, субдомінантами за бюджетами часу та маси - сойка, повзик, вільшанка. Співвідношення навантаження на концентри за бюджетом часу таке: перший $-26,00 \%$, другий - 68,22 \%, третій - 5,78\%. Значний показник для першого концентру пояснюється активним живленням жолудями двох видів повзика та сойки. Велика дольова участь сойки $є$ також показником інтенсивності форичних зв'язків цього птаха 3 дубом. 3 наведеного можна зробити висновок, що основною масою саме жолуді зрілого та старого генеративного дуба за допомогою сойки потрапляють у цикл відновлення дуба. Загалом характер участі птахів у трофічних зв'язках не дуже різноманітний, дольова участь інших видів коливається в межах від 1,06 до 4,54\% за показниками бюджетів часу та маси. Це $\epsilon$ наслідком процесу зміни консортивних угруповань птахів в осінній період.

В осінній період спостерігаються перші випадки формування зграй птахів за типом зимових угруповань, але ці зграї не мають інтегрованої форми трофічних зв'язків (тобто взаємодопомоги під час добування їжі), і швидко розпадаються за умов сонячної та теплої погоди восени.

Топічна складова консортивних зв'язків птахів з дубом (рис. 1, B3) складається 3 топічних зв'язків 9 видів і має 4 види топічних зв'язків. Домінантом $є$ велика синиця, субдомінантами - вільшанка та звичайна вівсянка. На відміну від молодого генеративного дуба, найбільше різноманіття топічних зв'язків виявляє велика синиця -4 , субдомінанти 3 і 1 вид зв'язку відповідно. Дольова участь інших видів птахів коливається в межах від 0,56 до 5,35 \% від денного бюджету часу. Це свідчить про зменшення різноманіття способів взаємодії птахів з автотрофом.

Таким чином, консортивні угруповання птахів в осінній період проходять процес перебудови i 3 проходженням цього сезону все більше набувають ознак зимових угруповань. Зменшується бюджет часу, видовий склад консортів, різноманіття функціональних зв'язків. 3 іншого боку, виявляються різновиди зв'язків, які демонструють реальний стан консорцій. Саме зрілі консортивні угруповання дуба мають зв'язки птахів 3 першим концентром. Більш стабільною протягом літа та осені $\epsilon$ також участь птахів у третьому концентрі. Врівноважене співіснування птахів та інших природних ентомофагів $\epsilon$ запорукою більш стабільного контролю за популяціями основних фітофагів, які живляться фітомасою дуба.

Зимовий період існування консорції дуба характеризується більш сталими, але нечисельними угрупованнями, також у цей період спостерігається низький рівень різноманіття зв'язків та інтенсифікація трофічної діяльності угруповань птахів. Необхідність здобування їжі разом з ії низькою доступністю взимку призводить до живлення досить одноманітними трофічними ресурсами, які здобуваються 3 найменшими затратами енергії.

Консортивне угруповання птахів у віргінільного дуба в зимовий період $\epsilon$ дуже бідним, тому що ця категорія дуба не підтримує потужної трофічної бази для птахів. Трофічних зв'язків птахів з дубом у віковому стані $v$ не зафіксовано взагалі. Загальний бюджет часу на $100 \%$ складається 3 топічних зв'язків (див. табл. 1). Топічні зв'язки (рис. 2, $A 3$ ) у цьому консортивному угрупованні виявляє тільки один вид - блакитна синиця. Цей вид має тільки два види топічних зв'язків з віргінільним дубом. Таким чином, консортивне угруповання віргінільного дуба вирізняється вкрай нестійкою організацією у зимовий період. Це свідчить про те, що ця категорія дуба не втягнута в загальний стабільний обмін речовини та енергії липово-ясеневих дібров.

Консортивне угруповання молодого генеративного дуба $\epsilon$ більш різноманітним та сталим. Показники бюджетів часу $є$ найбільшими серед усіх категорій дуба в зимовий період (див. табл. 1). Більшу частину бюджету часу консортивних зв'язків складають трофічні - 21,86 \pm 8,3 сек. Топічна складова бюджету часу дорівнює $2,76 \pm$ 0,56 сек. Незважаючи на високі для зимового часу показники активності, видовий склад птахів цього угруповання не дуже великий - 7 видів. Загальні тенденції схожі на ті, що формують склад консорції цього дуба в інші сезони року. Тобто вплив специфічного розташування дуба на освітлених позиціях та досить потужна трофічна база, яка складається з популяцій фітофагів, заохочують не дуже широкий, але активний видовий склад птахів.

Система трофічних зв'язків (рис. 2, Б1, Б2) характеризується домінуванням блакитної синиці, яка $є$ найактивнішим консортом більшості деревних порід липово-ясеневих дібров у зимовий період, субдомінантами 


\section{відсутні}

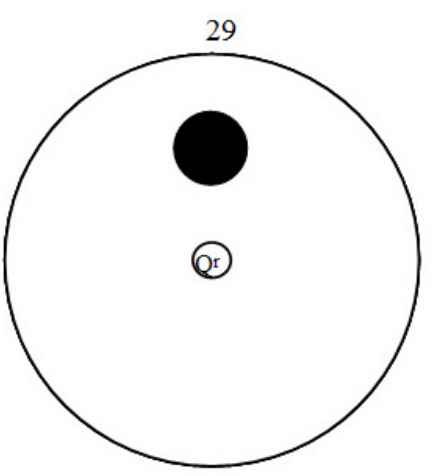

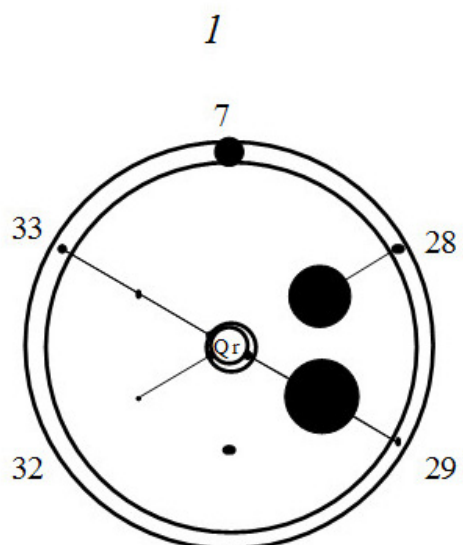

30

1

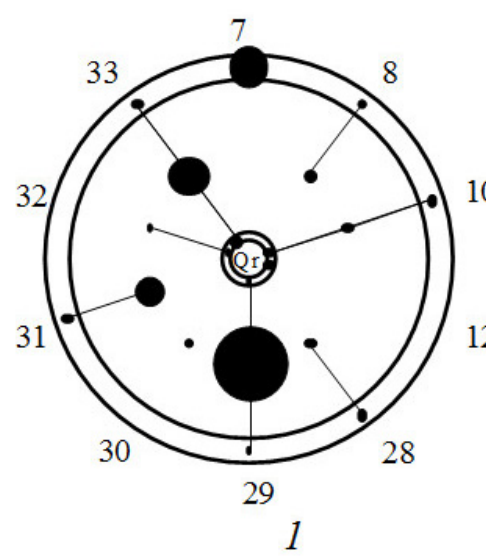

відсутні

2

${ }_{7}$ Б

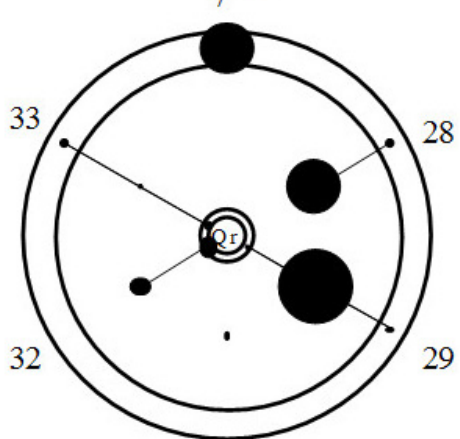

30

2

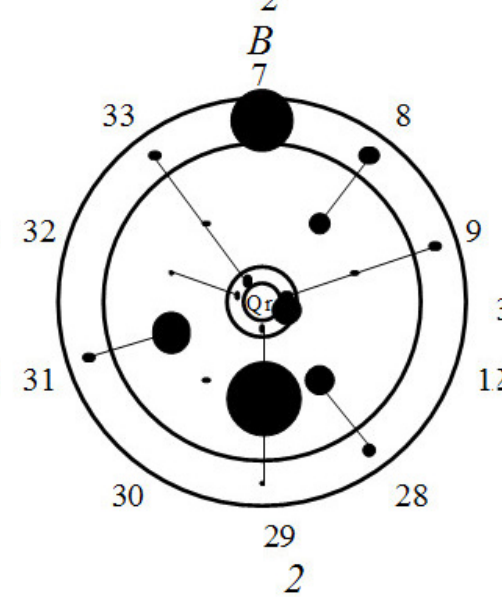

3

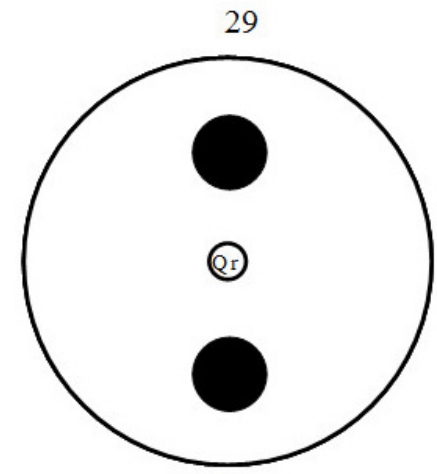

39

3

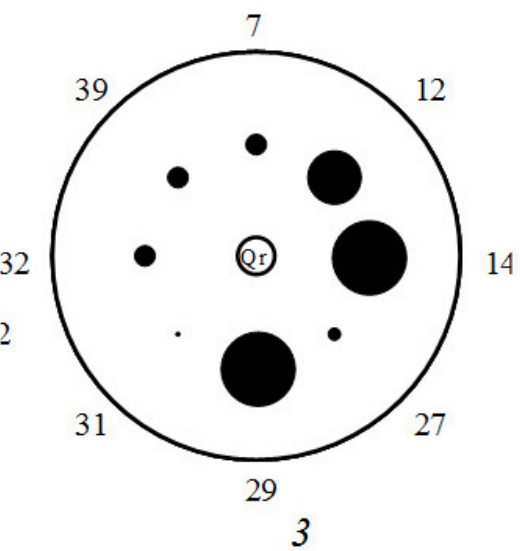

Рис. 2. Схеми консортивних зв'язків птахів з дубом звичайним за бюджетами часу та маси на один екземпляр автотрофа в зимовий період: А - віргінільним - v; Б - молодим генеративним $-g 1$; В - зрілим та старим генеративним - g2-g3;

1 - трофічних зв'язків за бюджетом часу; 2 - трофічних зв'язків за бюджетом маси; 3 - топічних зв'язків за бюджетом часу.

Номерами на схемах позначено консортивні зв'язки видів: 1 - Accipiter gentilis; 2 - Buteo buteo; 3 - Cuculus canorus;

4 - Strix aluco; 5 - Jynx torquilla; 6 - Picus canus; 7 - Dendrocopos major; 8 - Dendrocopos medius; 9 - Dendrocopos mino;

10 - Anthus trivialis; 11 - Oriolus oriolus; 12 - Garrulus glandarius; 13 - Corvus cornix; 14 - Bombycilla garrulus;

15 - Sylvia atricapilla; 16 - Sylvia curruca; 17 - Sylvia communis; 18 - Phylloscopus collybita; 19 - Phylloscopus sibilatrix;

20 - Muscicapa striata; 21 - Ficedula hypoleuca; 22 - Ficedula albicollis; 23 - Erithacus rubecula; 24 - Luscinia luscinia;

25 - Turdus merula; 26 - Turdus philomelos; 27 - Turdus viscivorus; 28 - Aegithalos caudatus; 29 - Parus caeruleus;

30 - Parus palustris; 31 - Parus major; 32 - Sitta europaea; 33 - Certhia familiaris; 34 - Passer montanus; 35 - Fringilla coelebs; 36 - Chloris chloris; 37 - Carduelis carduelis; 38 - Pyrrhula pyrrhula; 39 - Coccothraustes coccothraustes; 40 - Emberiza citrinella.

$€$ звичайний дятел (за бюджетом маси) та синиця довгохвоста - вид, який є кочівним у зимовий період і не перебуває постійно в липово-ясеневій діброві. Таким чином, у консортивному угрупованні птахів $є$ помітний вплив мігруючих елементів. Дольова участь інших видів у бюджеті часу та маси коливається в межах від 0,36 від 7,42 \%. Співвідношення активності по концентрах (I - 3,71\%, II $86,21 \%$, III - 10,08 \%) характеризується переважанням другого концентру. Третій концентр відрізняється своєю сталістю й істотно не відрізняється від літнього співвідношення, особливістю цієї частини трофічних зв'язків є активна участь у ній звичайного дятла, який взимку в липово-ясеневих дібровах живиться, за даними Романєєва (Romaneev, 1973), виключно мурахами. Перший концентр забезпечується трофічними зв'язками трьох видів: блакитної синиці, підкоришника звичайного, повзика. У двох перших видів рослинна їжа є супутньою, тобто попадає у шлунок птахів під час добування комах під корою. Повзик у зимовий період крім комах живиться жолудями, схованими восени у «коморах» у щілинах кори 
та дуплах дуба і є активним споживачем рослинної біомаси в зимовий період.

Топічна складова консортивних зв'язків молодого генеративного дуба взимку є дуже слабо розвинутою (рис. 2, Б3). Видовий склад представлений 2 видами - костогризом та блакитною синицею. Домінантом є блакитна синиця. Різноманіття самих зв'язків теж незначне (3 види), але це $\epsilon$ наслідком загального зменшення обсягу консортивних зв’ язків у зимовий період.

Зимове консортивне угруповання зрілого та старого генеративного дуба $\epsilon$ найпотужнішим за кількістю видів птахів-консортів - 13 видів. Загальний бюджет часу дещо поступається такому у молодого генеративного дуба (див. табл. 1). Основу його складає трофічна частина зв'язків $19,04 \pm 5,36$ сек. Це пояснюється загальною тенденцією збільшення витрат на здобування їі у птахів взимку. Топічна складова суттєво поступається трофічній.

Трофічна складова консорції зрілого та старого генеративного дуба більш різноманітна за видовим складом, ніж така в молодого генеративного дуба 10 видів (рис. 2, B1, B2). Це свідчить на користь того, що ця вікова категорія дуба в зимовий період відіграє важливу роль у підтриманні зимового населення птахів липово-ясеневих дібров. На відміну від дуба у віці $g 1$, схема трофічних зв'язків зрілого та старого генеративного дуба орієнтована на постійне зимове орнітонаселення липово-ясеневих дібров. Домінантом серед птахів у консорції вищевказаної вікової категорії дуба $є$ блакитна синиця. Субдомінантом - звичайний дятел. Дольова участь інших видів у бюджетах часу та маси коливається в межах від 0,93 до 9,97 \%. Співвідношення діяльності птахів по концентрах дещо змінюється порівняно з дубом у віці $g 1$ (I - 4,66 \%, II - 82,21\%, III - 13,13\%). Досить високий показник першого концентру $\epsilon$ наслідком трофічної діяльності головним чином сойки, яка взимку активно споживає жолуді із своїх «комор», крім неї жолуді у незначній кількості споживає повзик. Рослинна їжа у спектрі живлення інших видів $є$ супутньою і споживається під час здобування основної їжі - комах. Існування третього концентру пояснюється перш за все активною трофічною діяльністю звичайного дятла.

Топічна складова консорції зрілого та старого генеративного дуба $\epsilon$ набагато складнішою та розвиненішою, ніж така в молодого генеративного дуба (рис. 2, B3). У топічних зв'язках з дубом $g 2-g 3$ беруть участь 7 видів птахів. Незважаючи на низький показник середнього бюджету часу на один екземпляр автотрофа, птахи виявляють 5 видів топічних зв'язків. Домінантом у цій частині консортивних зв'язків $є$ блакитна синиця, субдомінантами - омелюх та сойка. Дольова участь інших видів коливається в межах від 2.02 до 3,69 \% від бюджету часу топічних зв'язків. Характерною рисою топічного консортивного угруповання $\epsilon$ те, що основу його складають види, які в зимовий час постійно зустрічаються в межах липово-ясеневих дібров. Це ще раз підтверджує стабільний характер консортивного угруповання птахів зрілого та старого генеративного дуба в зимовий період.

Весняний період у функціонуванні консорцій вирізняється бурхливим за темпами процесом становлення гніздових угруповань птахів i, відповідно, найвищим рівнем різноманіття та інтенсивності консортивних зв'язків. Консортивне угруповання віргінільного дуба у весняний період, незважаючи на високі показники, має нестійкий характер, тому що в консортивних зв'язках беруть участь тільки 5 видів (рис. $3, A$ ). Основу загального бюджету часу, на відміну від літа та осені, складають топічні зв' язки - 174,25 $\pm 8,73$ сек. (див. табл. 1).

Трофічна складова консортивного угруповання цієї категорії дуба (рис. 3, A1, A2) є бідною за видовим складом 2 види (кропив'янка сіра та велика синиця). Домінантом $є$ другий вид. Співвідношення по концентрах: I - 0,00 \%, II $88,7 \%$, III - 11,3\%. Характерною рисою $є$ відсутність активності птахів у першому концентрі. Дольова участь у третьому концентрі є звичайною для дуба - наближається до $10 \%$ бюджету часу трофічних зв'язків. Типовим явищем також $\epsilon$ те, що жоден 3 двох видів не був зафіксований як облігатний трофічний консорт. Це також свідчить про нестабільність угруповання.

Топічна складова консортивних зв'язків віргінільного дуба весною також (рис. 3, A3) досить бідна на види. Усього в схемі топічних зв'язків їх було зафіксовано 4. Домінантом, як і в трофічній складовій, $є$ сіра кропив'янка, субдомінантів немає. Дольова участь інших видів коливається в межах від 1,87 до 6,74 \% бюджету топічних зв'язків. Як і в трофічній частині зв'язків, не було зафіксовано жодного облігатного консорта. Незважаючи на це, топічна складова досить різноманітна на види топічних зв'язків. Усього їх будо зафіксовано 5. Найбільше їх різноманіття на віргінільному дубі має домінантний вид сіра кропив'янка. Три види зв'язків було зафіксовано у звичайної вівсянки. Два інших види виявили по одному різновиду зв'язків. Таким чином, консортивне угруповання птахів навіть у весняний період не $є$ сталим, оскільки має непостійну і бідну на види трофічну складову. Високі ж показники топічної складової $\epsilon$ наслідками загальної інтенсифікації топічних зв'язків птахів у весняний період у зв'язку з підготовкою до розмноження.

Консортивне угруповання птахів молодого генеративного дуба весною значно багатіше на види, ніж віргінільного. Усього у складі консорції цього дуба у весняний період було зафіксовано 16 видів птахів. Загальні показники даного консортивного угруповання у птахів $\epsilon$ невисокими для весняного періоду (див. табл. 1). Більшу його частину складає бюджет топічних зв'язків $-179,40 \pm$ 10,95 сек (див. табл. 1).

Трофічна складова консортивних зв'язків птахів 3 молодим генеративним дубом (рис. 3, Б1, Б2) поєднує у своєму складі взаємодії 3 дубом 10 видів птахів. Співвідношення по концентрах: I - 0,10\%, II - 87,16\%, III - $12,74 \%$ за бюджетом часу. Участь птахів у першому концентрі $є$ супутньою (випадкове потрапляння шматочків рослинної речовини разом із комахами у шлунок птаха) $\mathrm{i}$ тому має дуже низький показник. Активність щодо третього концентру істотно не відрізняється від такої у віргінільного дуба (рис. $3, A, D$ ). Домінантом у трофічних зв'язках за бюджетом часу $\epsilon$ вівчарик-ковалик, за бюджетом маси - зяблик, співдомінантами - велика та блакитна синиця, звичайний дятел. Дольова участь інших видів коливається в межах від 0,49 до 8,29 \% від бюджетів часу та маси. На відміну від віргінільного дуба, найбільш активними консортами $є$ лісові види. Таким чином, i y весняний період молодий генеративний дуб відіграє роль середовищеутворювача.

Топічна складова консортивних взаємодій (рис. 3, Б3) має зв'язки 13 видів птахів-консортів. Порівняно 3 віргінільним дубом, збільшується також і різноманіття топічних зв'язків. Весною у консорції молодого генеративного дуба їх зафіксовано 7 видів. Таким чином, молодий генеративний дуб активно сприяє формуванню гніздових угруповань птахів, які в подальшому у період вегетації будуть обмежувати діяльність фітофагів першого концентру. Недоліком даної частини консорції молодого генеративного дуба $є$ досить низькі загальні показники бюджету часу топічних зв'язків. Домінантом серед топічних консортів є вівчарик-ковалик, субдомінантами співочий дрізд, зяблик та костогриз. Усі $є$ лісовими видами. Незважаючи на досить розвинуту структуру топічних зв'язків, кожен 3 видів-консортів даної вікової категорії дуба не виявляє значного різноманіття зв'язків. Найбільше їх виявлено в костогриза - 4. Інші види мають від 1 до 3 видів топічних зв'язків. Це свідчить про нерозвиненість самої структури зв'язків. Таким чином, консортивне угруповання молодого генеративного дуба взагалі i y весняний період зокрема має риси дуже динамічного, але не зовсім розвиненого угруповання. 

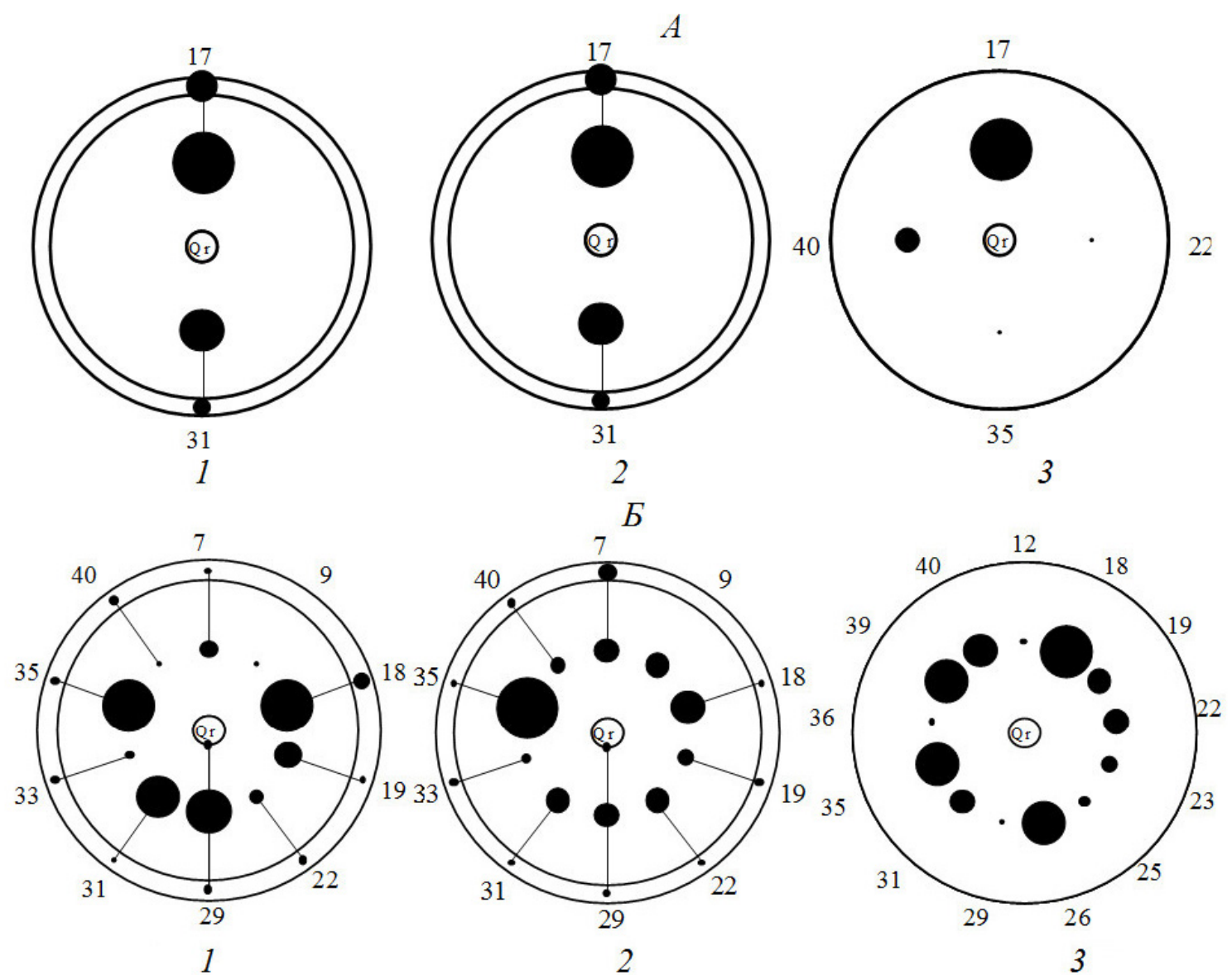

1

2

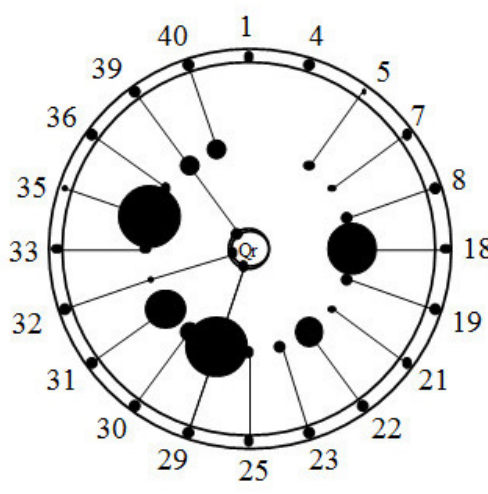

1

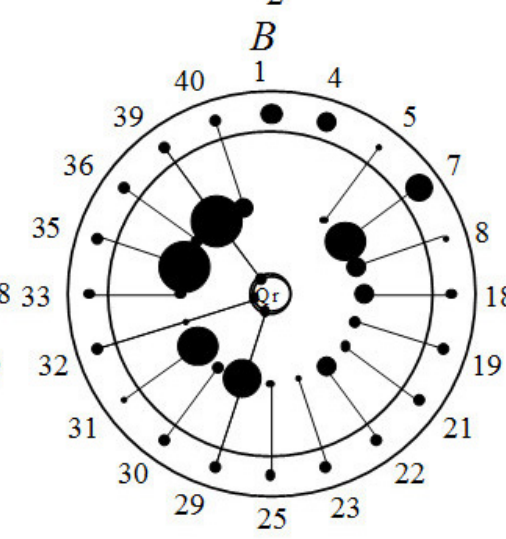

2

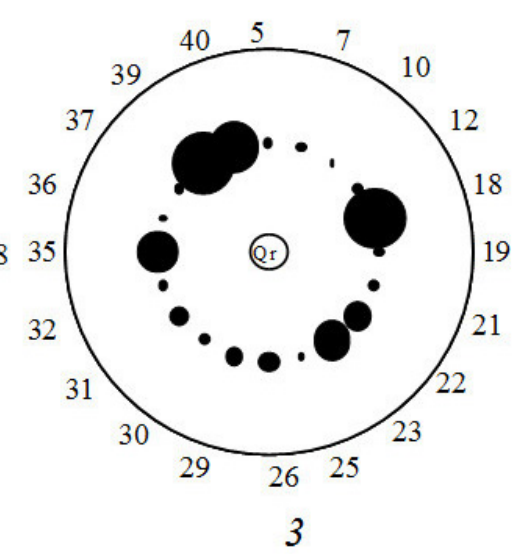

Рис. 3. Схеми консортивних зв'язків птахів з дубом звичайним за бюджетами часу та маси на один екземпляр автотрофа у весняний період: А - віргінільним - $v$; Б - молодим генеративним $-g 1$; В - зрілим та старим генеративним - g2-g3;

1 - трофічних зв'язків за бюджетом часу; 2 - трофічних зв'язків за бюджетом маси; 3 - топічних зв'язків за бюджетом часу.

Номерами на схемах позначено консортивні зв'язки видів: 1 - Accipiter gentilis; 2 - Buteo buteo; 3 - Cuculus canorus;

4 - Strix aluco; 5 - Jynx torquilla; 6 - Picus canus; 7 - Dendrocopos major; 8 - Dendrocopos medius; 9 - Dendrocopos mino;

10 - Anthus trivialis; 11 - Oriolus oriolus; 12 - Garrulus glandarius; 13 - Corvus cornix; 14 - Bombycilla garrulus;

15 - Sylvia atricapilla; 16 - Sylvia curruca; 17 - Sylvia communis; 18 - Phylloscopus collybita; 19 - Phylloscopus sibilatrix;

20 - Muscicapa striata; 21 - Ficedula hypoleuca; 22 - Ficedula albicollis; 23 - Erithacus rubecula; 24 - Luscinia luscinia;

25 - Turdus merula; 26 - Turdus philomelos; 27 - Turdus viscivorus; 28 - Aegithalos caudatus; 29 - Parus caeruleus;

30 - Parus palustris; 31 - Parus major; 32 - Sitta europaea; 33 - Certhia familiaris; 34 - Passer montanus; 35 - Fringilla coelebs; 36 - Chloris chloris; 37 - Carduelis carduelis; 38 - Pyrrhula pyrrhula; 39 - Coccothraustes coccothraustes; 40 - Emberiza citrinella.

Весняне консортивне угруповання птахів зрілого та старого генеративного дуба $(g 2-g 3) \in$ найпотужнішим серед деревних порід. Перш за все він помітно відрізняється від інших порід загальними показниками консортивних зв'язків. Загальний бюджет часу на один екземпляр автотрофа $\epsilon$ найвищим (див. табл. 1). Цей показник більший навіть ніж у літній період. На відміну від літнього періоду, кількість видів птахів-консортів дещо менша -22 види. Як і в літній період, більшу частину його складають топічні зв'язки - близько 63 \% від загального бюджету часу. Поряд 3 цим доля топічних зв'язків у весняний період зростає i порівняно 3 молодим генеративним дубом (див. табл. 1). Абсолютні показники топічних зв'язків птахів цих двох вікових категорій дуба відрізняються більш ніж у 10 разів. Це свідчить про те, що зрілий та старий генеративний дуб $є$ головним середовищеутворювачем, який відповідає вимогам багатьох видів птахів-консортів.

У системі трофічних зв'язків зрілого та старого генеративного дуба весною беруть участь 18 видів птахів 
(рис. 3, B1, B2). Домінантом у системі трофічних зв'язків $\epsilon$ зяблик, субдомінантами - блакитна синиця та вівчарикковалик. Дольова участь інших видів коливається в межах від 0,23 до 9,07 \% від загальних бюджетів часу та маси. Співвідношення по концентрах: I - 1,28 \%, II - 90,63\%, III $8,09 \%$ за бюджетом часу. У роботі першого концентру беруть участь блакитна синиця, повзик та костогриз (див. рис. $3, B 1$, B2). Спеціалізована фітофагія весною зафіксована тільки для останнього - це поїдання $\mathrm{y}$ незначних кількостях бруньків. Участь у третьому концентрі наближається до рівня $10 \%$ і є типовою для дуба на генеративній стадії розвитку.

Топічна складова консорції дуба у віці $g 2-g 3$ весною $€$ найрозвиненою, у ній беруть участь 20 видів птахів (рис. 3 , B3). Домінант - вівчарик-ковалик, субдомінанти костогриз та звичайна вівсянка. Дольова участь інших видів птахів коливається в межах від 0,1 до $9,43 \%$ від бюджету часу топічних зв'язків. Загальна кількість видів топічного зв'язку птахів така сама, як і в молодого генеративного дуба. На відміну від дуба $g l$, значно зростає різноманіття топічної діяльності кожного з видів. Якщо середній показник кількості видів зв'язків кожного виду птахів на дубі у віці $g 1$ дорівнює 2,46, то такий же показник для дуба у віці $g 2-g 3$ вже дорівнює 3,2 . На відміну від дуба $g 1$, з'являються види, які мають 5-7 видів топічного зв'язку з автотрофом (зяблик, вівчарик-ковалик, костогриз, звичайна вівсянка, велика синиця, мухоловка білошия). Три види птахів виявляють 4 види топічного зв'язку (блакитна синиця, лісовий щеврик, співочий дрізд). Таким чином, майже кожен вид значно розширює різноманіття своєї активності на зрілому та старому генеративному дубі.

\section{Висновки}

Консортивні угруповання дуба звичайного протягом усього року зберігають основні риси своєї організації. Віргінільний дуб має стохастичний характер взаємодії птахів 3 ядром консорції, характеризується практично повною відсутністю облігатних консортів-птахів. Молодий генеративний дуб за рахунок інтенсивного лінійного росту активно формує систему трофічних зв'язків 3 консортами, перш за все створюючи загальні показники - бюджети часу та маси. Консорція зрілого та старого генеративного дуба значно розширює кількість видів птахів-консортів та урізноманітнює характер їхньої взаємодії. Це може сприяти підвищенню стабільності консортивних угруповань. У більшості випадків у консорціях дуба першою формується трофічна складова консорції, потім топічна. Значною мірою на функціонування консорцій дуба впливає специфічне розташування віргінільного та молодого генеративного дуба на освітлених позиціях у липово-ясеневих дібровах. Найбільш ефективним показником, який свідчить про високий рівень розвитку консорції, $є$ кількість видів взаємодій між консортом та автотрофом. Стабільність консортивних зв'язків птахів 3 дубом звичайним протягом усього сезону зростає у напрямку від віргінільного дуба до зрілого та старого генеративного. Нестійкі консортивні угруповання віргінільного дуба мають коливання за кількістю видів протягом року до $100 \%$ (за вихідну величину обрано кількість видів улітку), угруповання молодого генеративного дуба - 81,82 \%, зрілого та старого генеративного дуба - 59,26 \%. Таким чином, протягом року консорції зрілого та старого генеративного дуба найбільш активно приваблюють види-сезонники, які взаємозамінюють один одного. Цим досягається цілорічна стабільність контролю за популяціями фітофагів.

\section{References}

Apostolov, L. G., Bulakhov, V. L., Gubkin, A. A. (1968). Kharakteristika pitaniya ptenczov nekotory`kh vorob 'iny`kh pticz $\mathrm{v}$ usloviyakh lesov srednego techeniya r. Orel’
[Characteristics of the nutrition of passerines chicks in the forests of the Orel River region]. Voprosy stepnogo lesovedeniya, 1, 156-163 (in Russian).

Beklemishev, V. N. (1951). O klassifikatsii biogeotsenologicheskih (simfiziologicheskih) svyazey [On the classification of biogeocenotic (symphysiological) connections]. Byulleten MOIP, 55(5), 3-30 (in Russian).

Belgard, A. L. (1960). K teorii strukturyi iskusstvennogo lesnogo soobschestva $\mathrm{V}$ stepi [To the theory of the structure of an artificial forest community in the steppe]. Iskusstvennyie lesa stepnoy zonyi Ukrainyi. Harkov: HGU. 17-32 (in Russian).

Belgard, A. L. (1971). Stepnoe lesovedenie [Steppe forest science]. Moscow, Lesnaya promyishlennost (in Russian).

Chaplygina, A. B., Yuzyk, D. I., Savynska, N. O. (2016a). The robin, Erithacus rubecula (Passeriformes, Turdidae), as a component of autotrophic consortia of forest cenoses, Northeast Ukraine. Vestnik zoologii, 50(4), 369-378.

Chaplygina, A. B., Yuzyk, D. I., Savynska, N. O. (2016b). The robin, Erithacus rubecula (Passeriformes, Turdidae), as a component of heterotrophic consortia of forest cenoses, Northeast Ukraine. part 2. Vestnik zoologii, 50(6), 493-502.

Dolnik, V. V. (1982). Metodyi izucheniya byudzhetov vremeni i energii u ptits. [Methods of studying budgets of time and energy in birds]. Trudyi Zoologicheskogo institute, 113, 3-37 (in Russian).

Grigorenko, O. S., Lyindya, A. G. (1977). K ekologii duba chereshchatogo, yasenya obyiknovennogo, klenov ostrolistnogo, polevogo, i lipyi melkolistnoy, proizrastayuschih v dubravah Prisamarya [To the ecology of oak, ash, maples and linden, growing in the oak forests of Prisamarya]. Voprosyi stepnogo lesovedeniya i ohranyi prirodyi, 8, 75-81 (in Russian).

Gubkin, A. A. (1979). Gnezdyashhayasya ornitofauna lesny'kh nasazhdenij Dnepropetrovshhiny', eyo raspredelenie i otnositel'naya chislennost' [Nesting avifauna of forest plantations of the Dnepropetrovsk region, its distribution and relative abundance]. Voprosy' stepnogo lesovedeniya, bioczenologii i okhrany` prirody`, 9, 68-74 (in Russian).

Inozemczev, A. A. (1978). Rol' nasekomoyadny'kh pticz v lesny kh bioczenozakh [The role of insectivorous birds in forest biocenoses]. Leningrad, LGU (in Russian).

Korol 'kova, G. E. (1963). Vliyanie pticz na chislennost' vredny`kh nasekomy 'kh [The effect of birds on the number of harmful insects]. Moscow, AN SSSR (in Russian).

Mazing, V. V. (1966). Konsortsii kak elementyi funktsionalnoy strukturyi biogeotsenozov [Consortia as elements of the functional structure of biogeocenosis]. Trudyi MOIP, 27, $117-126$ (in Russian).

Ponomarenko, O. L. (2005). Dy'namika funkcional'nogo skladu ugrupovan' ptaxiv $u$ indy'vidual'ny'x konsorciyax ly'py' sercely`stoyi (Tilia cordata) [Dynamics of the birds groups functional composition in individual consortia of linden (Tilia cordata)]. Visny`k Dnipropetrovs`kogo universy`tetu. Biologiya. Ekologiya, 13(1), 226-231 (in Ukrainian).

Ponomarenko, O. L. (2007). Formuvannya konsorty'vny`x zv"yazkiv ptaxiv u indy`vidual'ny`x konsorciyax klena pol'ovogo (Acer campestre) protyagom jogo ontogenezu [Formation of conservative bird connections in individual consortia of maple (Acer campestre) during its ontogenesis]. Py`tannya stepovogo lisoznavstva ta lisovoyi rekul'ty vaciyi zemel', 11(36), 127-132 (in Ukrainian).

Ponomarenko, O. L. (2006). Rozvytok konsortyvnykh zviazkiv ptakhiv $\mathrm{v}$ indyvidualnykh konsortsiiakh duba zvychainoho (Quercus robur L.) protiahom yoho ontohenezu [Development of consortium bird connections in individual consortia of oak (Quercus robur L.) during its ontogenesis]. Pytannia stepovoho lisoznavstva ta lisovoi rekultyvatsii zemel, 10(35), 134-143 (in Ukrainian).

Ramenskiy, L. G. (1952). O nekotoryih printsipialnyih polozheniyah sovremennoy geobotaniki [Some basic principles of modern geobotany]. Bot.zhurnal, 37(2), 181-201 (in Russian). 
Romaneev, N. S. (1973). K kharakteristike povedeniya pticz pri zimnej doby'che korma [On the characteristic behavior of birds during winter forage production]. Voprosy`stepnogo lesovedeniya, 4, 169-171 (in Russian).

Smirnova, O. V., Zaugolnova, L. B., Taronova, N. A., Falikov, L. D. (1976). Kriterii vyideleniya vozrastnyih sostoyaniy i osobennosti hoda ontogeneza u rasteniy razlichnyih biomorf [Criteria for the identification of age-related conditions and features of the ontogenesis course in plants of various biomorphs]. Tsenopopulyatsii rasteniy (osnovnyie ponyatiya $\mathrm{i}$ struktura), 1. Moscow, Nauka. 14-43 (in Russian).

Sukachev, V. N. (1972). Opredelenie ponyatiya "lesnoy biogeotsenoz" ego komponentyi i osnovnyie svoystva [Definition of the term "forest biogeocenosis", its components and basic properties]. Izbrannyie trudyi, 1. Leningrad, Nauka. 329-356 (in Russian).

Tkachenko, M. E. (1955). Obschee lesovodstvo [Common forestry]. Moscow, Leningrad, Goslesbumizdat (in Russian).

Tryfanova, M. V., Kunakh, O. M., Zhukov, O. V. (2015). Doslidzhennya konsortyvnyh zv"yazkiv u biogeocenozax ta oxorona pryrody' [Investigation of consortial connections in biogeocoenoses and nature protection]. Dnipropetrovs'k, DNU (in Ukrainian).

Yuzyk, D. I., Chaplygina, A. B. (2015). Konsorty`vni zv"yazky` pol'ovogo gorobcya (Passer montanus) v umovax lisovy'x cenoziv Pivnichno-Sxidnoyi Ukrayiny` [Consortia interactions of field sparrow (Passer montanus) in conditions of forest cenosis of the North-Eastern Ukraine]. Berkut, 24(2), 142-147 (in Ukrainian). 